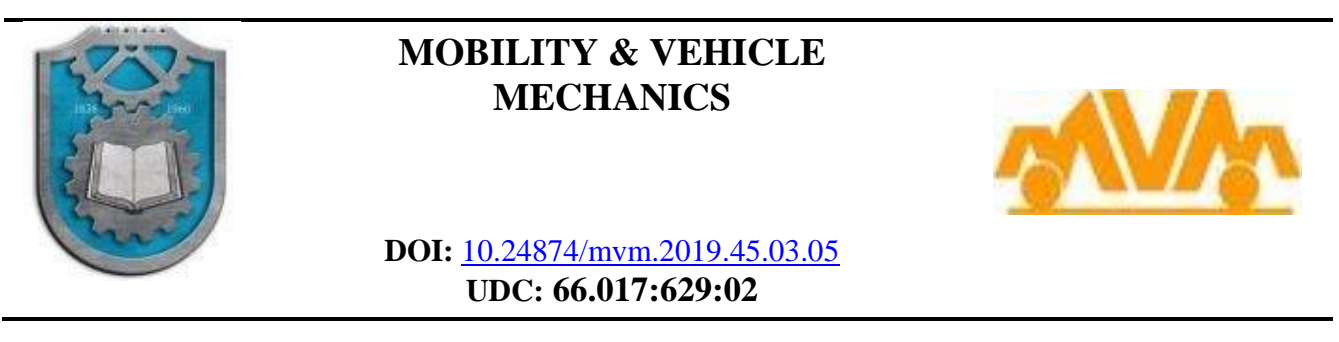

\title{
APPLICATION OF NANOCOMPOSITES IN THE AUTOMOTIVE INDUSTRY
}

\author{
Sandra Veličković ${ }^{{ }^{*}}$, Blaža Stojanović ${ }^{2}$, Lozica Ivanović ${ }^{3}$, Slavica Miladinović ${ }^{4}$, Saša \\ Milojević ${ }^{5}$
}

Received in September 2019, Accepted in October 2019

\section{RESEARCH ARTICLE}

\begin{abstract}
The development of new lightweight and strong materials and the design of new products are among the key elements for the development of new advanced construction and vehicle parts for the automotive industry. The use of composite materials in the automotive industry has been popular in recent decades due to the need to reduce vehicle weight, which directly affects fuel consumption and exhaust gases emission. In this way, the development of improved new materials with improved performance is accomplished. Nanocomposites represent a new class of materials that has excellent thermal and mechanical properties. The application of nanocomposites for development of automotive components is reflected in the improvement of the production rate, environmental and thermal stability, and the reduction in weight in the automotive industry, less wear parts, and indirectly to reduce $\mathrm{CO}_{2}$ emissions and environmental pollution. This research paper presents a review of the application of nanocomposites (metal, ceramic and polymeric) in the automotive industry.
\end{abstract}

(C) 2019 Published by University of Kragujevac, Faculty of Engineering

\footnotetext{
${ }^{1}$ Sandra Veličković University of Kragujevac, Faculty of Engineering, Sestre Janjić 6, 34000 Kragujevac, Serbia, sandrav@kg.ac.rs $(*$ Corresponding author)

${ }^{2}$ Blaža Stojanović, University of Kragujevac, Faculty of Engineering, Sestre Janjić 6, 34000 Kragujevac, Serbia, blaza@kg.ac.rs

${ }^{3}$ Lozica Ivanoić, University of Kragujevac, Faculty of Engineering, Sestre Janjić 6, 34000 Kragujevac, Serbia, lozica@kg.ac.rs

${ }^{4}$ Slavica Miladinović, University of Kragujevac, Faculty of Engineering, Sestre Janjić 6, 34000 Kragujevac,Serbia, slavicam@kg.ac.rs

5 Saša Milojević, University of Kragujevac, Faculty of Engineering, Sestre Janjić 6, 34000 Kragujevac,Serbia, sasa.milojevic@kg.ac.rs
} 
KEY WORDS: application, ceramic matrix nanocomposites, metal matrix nanocomposites, polymer matrix nanocomposites, vehicles

\section{PRIMENA NANOKOMPOZITA U AUTOMOBILSKOJ INDUSTRIJI}

REZIME: Razvoj novih laganih i jakih materijala i dizajn novih proizvoda su jedan od ključnih elemenata za razvoj nove napredne konstrukcije i delova vozila za automobilsku industriju. Upotreba kompozitnih materijala $\mathrm{u}$ automobilskoj industriji popularna je poslednjih decenija zbog potrebe za smanjenjem težine vozila, što direktno utiče na potrošnju goriva i emisiju izduvnih gasova. Na ovaj način se postiže razvoj poboljšanih novih materijala sa poboljšanim performansama. Nanokompoziti predstavljaju novu klasu materijala koji imaju odlična termička i mehanička svojstva. Primena nanokompozita za razvoj automobilskih komponenti ogleda se u poboljšanju brzine proizvodne, životne sredine i termičke stabilnosti i smanjenju težine u industriji vozila, smanjenju habanja delova i indirektno na smanjenje emisije $\mathrm{CO}_{2}$ i zagađenja životne sredine. Ovaj istraživački rad predstavlja pregled primene nanokompozita (metala, keramike i polimera) u industriji vozial.

KLJUČNE REČI: primena, keramička matrica nanokompozita, metalna matrica nanokompozita, polimerna matrica nanokompoziti, vozila 


\title{
APPLICATION OF NANOCOMPOSITES IN THE AUTOMOTIVE INDUSTRY
}

\author{
Sandra Veličković, Blaža Stojanović, Lozica Ivanović, Slavica Miladinović, Saša Milojević
}

\section{INTRODUCTION}

Automotive industry is constantly making efforts to the development and application parts that are light weight, and which at the same time possess excellent mechanical and tribological properties. Today, the automotive industry must meet certain requirements in terms of reducing fuel consumption and at the same time to maintain adequate comfort and safety of the vehicle. Another important factor is the weight of the vehicle, which has a direct impact on fuel consumption and thus the emission of toxic and harmful products of combustion [1-3].

The hardest part of the vehicle is the body shell, which makes $40 \%$ of its total weight. Therefore, the most common approach to lightweight design integrated within the structure of the vehicle which uses a combination of different materials, depending on their engineering properties and functional characteristics. In recent years increased use of highstrength steel, which in compact European cars makes 50 to $60 \%$ of the body. In addition to the use of steel, has increased the use of thermoplastics and thermoset composites used for coating bodywork, bonnet, roof components and other components of the body. The main materials used in the automotive industry are composites which are made of high-strength steel, aluminum, and composites of carbon fiber and plastic. Applying high-strength steel is achieved by lessening the weight by $20 \%$ compared to the conventional steel constructions, use of aluminum of $40 \%$ and $50 \%$ at the application of composites of carbon fiber. Therefore, by using light materials, reduces the weight of the vehicle, for example, the weight of aluminum ties in the suspension is smaller by $15 \%$ than the conventional, hollow composite shaft is $18 \%$ lighter than the conventional, and the application of forged aluminum rim saves up to $36 \%$ when compared to steel wheels [4].

Aluminum as a very light material is used as the main matrix element in the production of composite materials referred to as aluminum metal matrix composites (AMCs). Application of aluminum composite is widespread, from the military, automotive, flights until the space industry. AMCs compared with primary aluminum alloy have a good combination of mechanical and tribological properties. In addition, these properties can be tailored to the specific requests [1,2]. AMCs possess improved physical and mechanical properties such as strength to weight ratio, a good ductility, a high strength and a high modulus of elasticity, low thermal expansion coefficient, good wear resistance, good corrosion resistance, high temperature creep resistance, and better fatigue [5]. The use of lightweight materials for the production of automotive components also contributed to the reduction of air pollution.

Nanocomposites represent a new class of materials that exhibit excellent thermal and mechanical properties. Due to the high performance are suitable for use in aerospace, automobile, chemical and transport industry [2]. The first industrial production of nanocomposites in the automotive industry occurred in 1991 with the production of timing belt covers as part of the engine for Toyota Camry cars [6].

Most research and development based on nanotechnology is being implemented in the automotive sector. Nanotechnology is applied to parts of the body, chassis and tires, automotive interiors, electrical and electronics, IC engines and drive systems [7]. In recent years, remarkable progress has been made in various industries which motivated researchers to work on new structural materials for better performance in engineering applications. 
Tiruvenkadam $\mathrm{N}$. et al have made investigations of the use of the aluminum hybrid nanocomposite for the IC engine cylinder liner (NL) analyzing the performance, combustion and emission characteristics of the engine and others. The aim was to replace the piston cast-steel composite material with the base of $\mathrm{Al} 6061$ and Nano reinforcement zirconium dioxide $\left(\mathrm{ZrO}_{2}\right)$, silicon carbide $(\mathrm{SiC})$ and Solid lubricant graphite $(\mathrm{Gr})$ to the size of reinforcement $100 \mathrm{~nm}, 220 \mu \mathrm{m}$ and 100 microns, respectively. The mass fraction of each reinforcement amounted to $2.25 \mathrm{wt}$. \%. They concluded that the combination of the selected matrix with reinforcement suitable for NL based on the density, mechanical and thermal properties and of a homogeneous mixture is carried out based on SEM analysis. They also found that the application of NL can achieve greater in-cylinder pressure and higher efficiency. Applying NL is reduced emissions of $\mathrm{CO}, \mathrm{HC}$ and smoke quantity output, but the increased NOx emission [8].

Carvalho O. et al have applied a hybrid nanocomposite with an aluminum base for making the piston ring [9]. The material that was used is a hybrid nanocomposite with aluminum base reinforced with $\mathrm{SiC}$ particles, and nano MWCNT's of the order of $50 \mathrm{~nm}$, produced by hot-pressing technique in order to evaluate the different fraction of CNTs. The best results have shown abrasion in case of the $6 \mathrm{wt}$. \% CNTs, however, because the best ratio between mechanical and tribological properties of a piston rings are selected from the $2 \mathrm{wt}$. $\%$ of CNTs.

Testing of mechanical and tribological characteristics of the nanocomposite is executive for the production of connecting rods are Ramachandra M. et al [10]. The application of aluminum alloys with $99 \%$ of purity and reinforcement $\mathrm{n}-\mathrm{ZrO}_{2} 25 \mathrm{~nm}$ in size were made using the nanocomposite powder metallurgy technique for the production of connecting rods. Testing of wear is made to pin on disc wear testing machine. The study came to the conclusion that the nanocomposite has a higher value than the hardness of the material base, and also reduces wear nanocomposites.

The application of the nanocomposite with a base of aluminum A356-reinforced nano-particles of the CNT is used for making disc brakes and the drum [11]. Sundaram M. and Mahamane U. produced nanocomposite by the method of casting with mixing. Tests have shown that an increase in the mass fraction of nano reinforcement CNT based on the A356 leads to an increase in hardness, while reducing wear, and friction coefficient. Increasing the hardness of the nanocomposite with an increase in the value of reinforcement in the aluminum base and have found Ranaa R. et al [12]. They interrogators aluminum nanocomposite reinforcement with $\mathrm{SiC}$ is used for the preparation of camshafts. Stir the nanocomposite is produced casting method with the percentages by weight of reinforcement of $\mathrm{SiC}$ of 1 to $4 \mathrm{wt}$. \% And a particle size of $40 \mathrm{~nm}$ in the Al base. To improve the mechanical and tribological characteristics of aluminum nanocomposite came Asmatulu $\mathrm{R}$. et al [13]. LM6 alloy strengthened reinforcement nano $\mathrm{SiC}$ and $\mathrm{Al}_{2} \mathrm{O}_{3}$ in the relationship 0.5, 1.0, 1.5 and 2 wt. \% of a styrene casting method. Based on the results concluded that as such, the composite can be used in the automotive industry for the production of brake discs. Summarizes the application of a hybrid nanocomposite with aluminum base Al 356 and $\mathrm{Al}$ 7075 in the automotive industry have made Dhanabal S. et al. [14]. As reinforcement nano size is used various kinds of materials and by methods of making nanocomposites discussed with stirring casting and pressure casting. The study characterization of nanocomposites came to the result that the piston for making the best show nanocomposites with reinforcement $\mathrm{SiC}-\mathrm{Al}_{2} \mathrm{O}_{3}, \mathrm{Al}_{2} \mathrm{O}_{3}-\mathrm{MoS}_{2}, \mathrm{TiC}, \mathrm{Gr}$, for the piston ring are nanocomposites reinforced with $\mathrm{Al}_{2} \mathrm{O}_{3}$-graphite, drum brakes for the reinforcement $\mathrm{TiB}_{2}-\mathrm{SiC}$, the shaft reinforcement is $\mathrm{SiC}$, for camshaft reinforcement $\mathrm{SiC}-\mathrm{CNT}, \mathrm{Al}_{2} \mathrm{O}_{3}-\mathrm{TiC}$ and $\mathrm{Al}_{2} \mathrm{O}_{3}$ for valves. 
The aim of this research is reflected in the review of the application of nanocomposites with metal, polymer and ceramic base in the automotive industry, and anticipates further growth in the use of these composites. The increase in the use of nanocomposites for automotive components is expected from year to year because the use of these composites impact on reducing the weight of vehicles, environmental and thermal stability and promoting environmental actions.

\section{COMPOSITE MATERIALS}

Composite materials are produced by adding basic material of the reinforcement in order to improve certain characteristics, depending on the purpose of the selected base material and the reinforcement. The composites are used as a basic structural material in the aerospace and automotive industry is comprised of deformable metal base and the rigid ceramic as reinforcement. These compositions are known as a composite with a metal base (MMC-Metal Matrix Composite). The first level of classification of composite materials depending on the base material, in addition to existing MMC polymer matrix composites (PMC-Polymer Matrix Composite), a ceramic matrix when it is about composites with ceramic matrix (CMC-Ceramic Matrix Composite) [15, 16].

The second level of classification of composites relates to the shape of reinforcement - the particles, short fibers, laminar composites with continuous fibers and woven composites. In this category are braided and knitted fiber bundles (short fibers, continuous fiber laminated composites) and woven composites (braided and knitted fiber architectures are included in this category) [17]. When the composite material has reinforcement in which at least one dimension in the nanometer scale or less than $100 \mathrm{~nm}$, then the case of nanocomposites [16]. Therefore, the nanocomposites are composites that consist of the base material and the nano size of the reinforcement which do not dissolve in one another.

Nanocomposites reinforced particles are largely used in the automotive industry due to their ability to withstand high temperatures and pressures. Several manufacturing methods used to produce them. The main disadvantage of these materials is a lack of homogeneity in the dispersion of the particles as and weak links between the matrix and the particles. However, research and testing of nanocomposites are still underway about the process of obtaining and variations of certain parameters in order to overcome the aforementioned shortcomings.

\subsection{Metal Matrix Nanocomposites}

Nanocomposites reinforced particles are largely used in the automotive industry due to their ability to withstand high temperatures and pressures. Several manufacturing methods used to produce them. The main disadvantage of these materials is a lack of homogeneity in the dispersion of the particles as and weak links between the matrix and the particles. However, research and testing of nanocomposites are still underway about the process of obtaining and variations of certain parameters in order to overcome the aforementioned shortcomings.

Metal Matrix Nanocomposites (MMNC's) use ductile metallic matrix in which the ceramic reinforcement adds. Various properties of these composites is improved, including the density, the hardness, abrasion, deformation and corrosion resistance depending upon the reinforcement (type, type and content) and the matrix as a manufacturing process. MMNC's become important because composites are used in the industry [19]. Nano-particles as a reinforcement in metal matrix composites have been progressively replaced other types of reinforcement such as nano-fibers, nano-whiskers or nano-platelets. The main division is reinforcing the oxides, carbides, nitrides and borides. The most commonly used types of nanoparticles are: $\mathrm{SiC}, \mathrm{TiC}, \mathrm{WC}, \mathrm{TaC}, \mathrm{TiB}_{2}, \mathrm{AlN}$, and $\mathrm{Al}_{2} \mathrm{O}_{3}[18,20]$. For an easy and 
high-quality use in automobile components as a template for the production of MMNCs used low density metals such as aluminum $(\mathrm{Al})$, magnesium $(\mathrm{Mg})$, and titanium (Ti) [20]. Aluminum and aluminum alloys have found many applications in addition to the automotive and aerospace industry in conjunction with carbon-reinforced composites, and silicon carbide. Use of aluminum alloy (such as $\mathrm{Al}-\mathrm{Si}$ alloy) for a matrix is preferred because of its advantages, including low cost and easy workability [17].

The most important production methods that are used for aluminum composites are: stir casting, squeeze casting, compo casting and infiltration, spray deposition and powder metallurgy [17]. Stir casting ranks first among all the available techniques because of the low cost, the possibility of using a wide range of materials as well as on processing conditions, where they can be made with compositions up to $30 \%$ in the volume fraction of reinforcement [18].

Basic classification process for obtaining nanocomposites can be classified into three groups:

1. Solid state processes include different powder metallurgy techniques with modifications in the processing steps such as, high-energy ball mill, hot pressing, hot isostatic pressing, cold pressing followed by sintering treatment and extrusion

2. Liquid state processes include different processes such as casting, stir casting and squeeze casting list and

3. Semi-solid processes include recasting technique with its variants such as compo casting or in combination with squeeze casting list.

Figure 1 presents the predictions of application of aluminum in different types of vehicles.

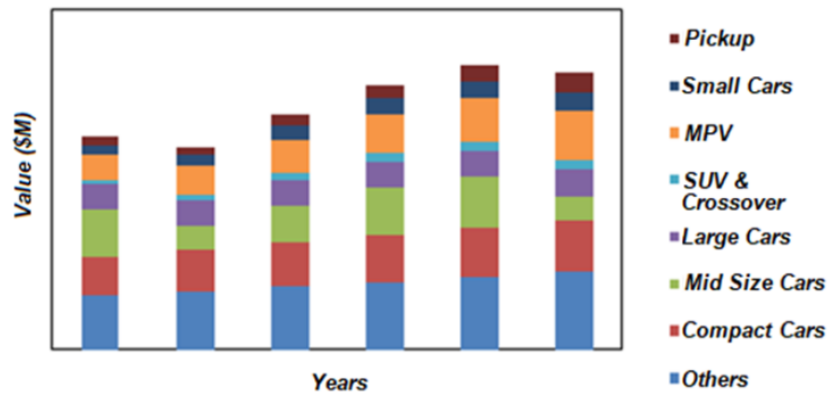

Figure 1. Application of aluminum from 2017 to 2022 [22]

Typical automotive parts which are made of a composite based aluminum alloys as a cylinder head (cylinder head), the pistons, the wheels, crankcase, cylinder head cover, intake manifold, the intake system and the drive means such as fork for a change-speed, drive shaft, gears, gear housing and so on. Application of aluminum castings in the field of automobile industry followed the development of the casting process, the melt treatment and thermal treatment. Great efforts have been made with the aim of improving mechanical and tribological characteristics, by controlling the microstructure that is by improving the processes for preparation, treatment of the metal melt and the heat treatment $[15,16]$. Research of composite materials precisely nanocomposites is still in progress. Researchers have been testing the nanocomposite concluded that they can be applied for the production of the respective parts of cars, such as the piston rings [8], the pistons [9], the connecting rods [10], the disc brakes and the drum brake [11], the camshaft [13], the shafts and the valves [14]. Nanoparticles are common by-products of combustion of oil and other 
hydrocarbon compounds, combustion and exhaust gases. As stated above, in the automotive industry uses a lot of materials with nanoparticles, and in recent years studies have shown that these nanoparticles can be found in water, air, soil, and therefore in the bodies of animals and humans. These results have led to a debate about toxicity and impact on the environment nanocomposites. Method maturities of nanoparticles in the human body by inhalation, absorption through the skin and if swallowed. Diseases that occur accumulation of nanoparticles in the body of the inflammatory airway disease, bronchitis, asthma, lung cancer, neurodegenerative diseases, cardiovascular disease, liver cancer, Parkinson's disease, Alzheimer's disease, Crohn's disease, and others. Because of these dangers should be given a lot of attention to protecting people during manufacture, transport, handling, use, disposal and recycling of parts and machines which in themselves have nanocomposites [13].

\subsection{Polymer Matrix Nanocomposites}

The polymers are excellent in terms of low density, ease of machining and the corrosion resistance, however, their rigidity and strength are much less than is required for structural applications. The polymers are considered to be suitable for structural applications matrices, due to their light weight, light processing and long-term stability [23].

Traditional micro reinforcement shall be replaced by nano-reinforcement in a polymer matrix, making a polymeric nanocomposite. These reinforcement leads to a significant improvement of certain structural and functional features of the polymer in relation to the polymer micro-reinforced reinforcement [4].

Polymer matrix nanocomposites (PMNCs) are a combination of materials wherein one dimension of the reinforcement is less than $100 \mathrm{~nm}$. The main conditions for the development are the low density PMNCs, ecological and high mechanical properties with a high production speed, good surface finish and with improved corrosion resistance, as well as better operating temperatures [18]. The preparation of nanocomposites uses a wide range of polymers, of which the most commonly used elastomers, thermoplastics and thermosets [23]. With the development of nanotechnology, various types of nano-reinforcement such as silicate nanoparticles are produced and used in the polymer materials to create so-called nanocomposites of polymer matrix (PMNCs). Uniform dispersion of nanoparticles in the polymer matrix leads to a significant improvement of the properties of the nanocomposites as compared to those of conventional reinforced composites micro particles [23, 24]. When the polymer matrix is added a small amount of the nanoparticles leads to improve the mechanical properties, the increase in resistance to cracking and propagation, as well as reducing the coefficient of thermal expansion (CTE) of the PMNCs. As reinforcement in polymeric materials for making these PMNCs, silica nanoparticles are used due to relatively high elastic modulus, low density, and good abrasion resistance, low coefficient of thermal expansion, high thermal stability, and low running costs [24]. There are different processes for the preparation of polymer nanocomposites and each of them has its advantages and disadvantages. As well as in the manufacture of nanocomposite of metal and this must be taken into account for selecting the appropriate method, which corresponds to the target application of the material, as well as the material properties, the ratio of the base and reinforcement, as well as the dispersion of the target performance. Solvent mixing, melt mixing, and in situ polymerization are some of the most common routes for nanocomposite synthesis [23, 25]. Automotive market has the largest market share of the polymeric nanocomposites thanks to widespread use such as a drive mechanism, the inner and outer power train, suspension and braking systems, exhaust systems and catalytic converters, lubrication, tires and body parts $[4,26]$. On the basis of more stringent legal regulations 
regarding standards of reducing emissions of cars is expected that the market of polymer nanocomposites recorded a significant increase in applications in the automotive and defense industries, as well as in aerospace engineering. It is expected that the production of nanocomposites result in reducing carbon dioxide emissions from cars. In addition to the automotive industry, the use of polymer composites is increased and the airline industry due to increased production of laminates, sandwich structure, lightning rods and anti-radar protection. Besides the already mentioned application of polymer composites are also used in bio-medicine at the recording of biological, cell tracking, the magnetic separation of biological, nanomedicine [26].

Other potential applications PMNCs in the automotive industry are as follows [18]: the cap of belt gear unit, the bonnet, fuel hoses, fuel valves, door frames, backrests, fuel hoses, and fuel valves, door frames, seat backs, step assists, heavy duty electrical enclosures, sail panel, box rails, fascia, grills, hood louvers, instrument panels, side trims, body panels, and fenders, sensors, fuel cells. Figure 2 shows the application of polymer nanocomposites with the parts of the car.

The automotive industry in Europe invests more than 5\% of annual turnover in research and development, and the main focus is on the development of better coatings and paints and stronger, more robust parts for end use. Therefore it is expected that the use of polymeric nanocomposites car market growth over the next ten years [6]. Overall, the use of plastics in the global market is promising for passenger cars, light commercial vehicles and heavy commercial vehicles. It is anticipated that the global plastics market by 2023 jump to 25.2 billion, and is predicted also a growth of $2.6 \%$ in the period from 2018 to 2023 .

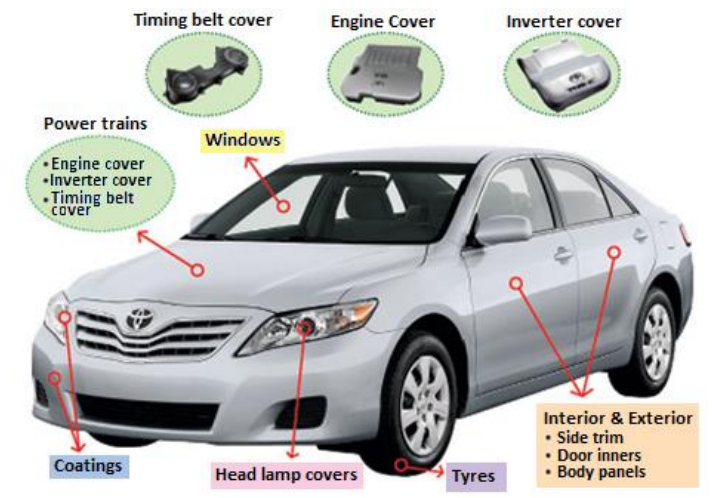

Figure 2. Illustration of the usage of polymer nanocomposites parts [6]

New trends have directly influence the dynamics of the plastic industry, including the development of technologies for recycling of plastic, and replace PA 66 with cheaper and more advanced PA 6. The diagrams, Figure 3 shows the prediction of application of polymeric materials from 2018 to 2023 . 


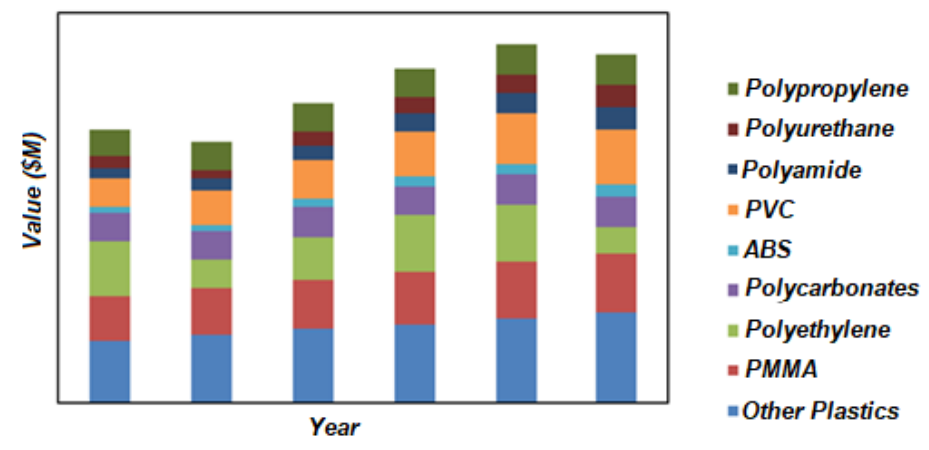

Figure 3. Histogram display forecasting application of polymeric materials in cars from 2018 to 2023 [22]

Trends, opportunities and market forecasts in the automotive industry until 2023, Figure 4 by type of vehicle: passenger cars, light-duty commercial vehicles and heavy-duty commercial vehicles. Based on the diagram in Figure 4 can be concluded that in the next five years, provides for reducing the use of heavy vehicles, indicating an increase in the application of new materials, i.e. nanocomposites.

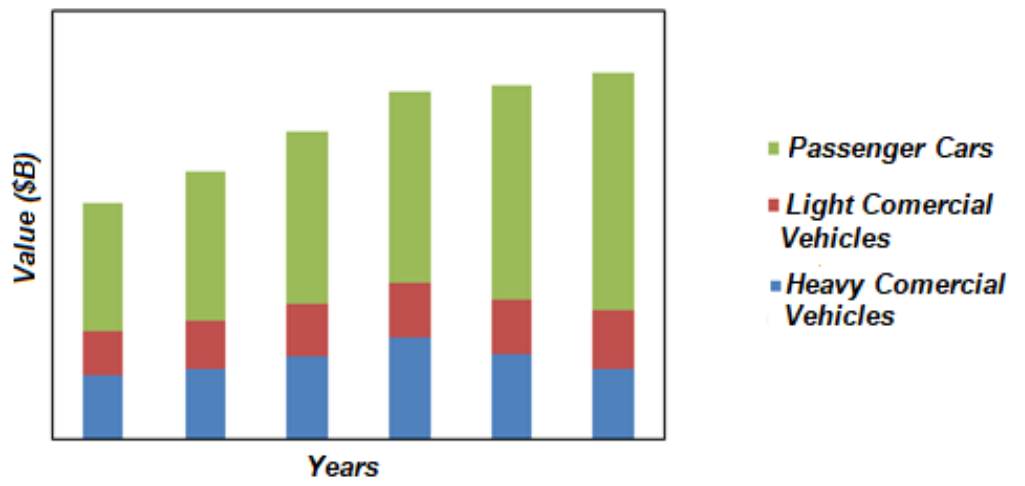

Figure 4. Histogram display forecasts car market in the world [6]

\subsection{Ceramic Matrix Nanocomposites}

Ceramic composites with dispersed metal particles represent a class of promising material for high performance applications in harsh environments, such as high temperature. These materials offer the possibility of combining a resistance to heat, resistance to degradation, and the abrasion resistance of the ceramic phase having a high mechanical strength and thermal conductivity is provided with metal phase. Ceramic matrix nanocomposites (CMNCs) is used for making nozzle assemblies, materials stoves, systems for converting energy, gas turbines, thermal engines, etc. [27]. The ceramic materials are insensitive to extremes of temperature as opposed to the steel at a high temperature changes the mechanical properties. In particular, they showed good composite materials reinforced with carbon fibers, which are very durable at high temperatures, have a high wear resistance, and have substantially lower specific weight compared with steel and aluminum. Carbon fiber 
reinforced composites are increasingly being used for car parts that are exposed to high loads, such as e.g. brake disks, valves, cylinder liners, spark plugs, sensors, isolators, filters, piston and others. Safe driving is achieved by applying the brake discs made of ceramic composites, because the discs have a great resistance to deformation and wear, thereby enabling a great savings in weight. Advantages of using the ceramic composite material in the automotive industry are: the ability to create very complex shapes, reduce the cost of after-treatment of parts, the possibility of connecting the parts during the manufacturing process, dimensional stability in extreme working conditions, corrosion resistance, ease of maintenance, longer life time, possibility to work-up and recyclability [28]. Disadvantages application of ceramic composite materials in the automotive industry are: the high cost of production, no serial production, the potential for products that are not in use, lack of skilled labor, cruelty (no deformability), sensitivity to moisture and temperature, inability to repair, toxicity, flammability, etc. Another downside application of ceramic materials is the tendency to fracture, expensive process of production and insufficient research [28].

The aforementioned disadvantages are the reason of low presence of micro and nanoceramic materials in the automotive industry which can be seen in the diagram in Figure 5.

Compared to conventional CMCs ceramic nanocomposites have improved hardness, high strength, toughness and creep resistance, thermal shock resistance, flame retardancy, magnetic and optical properties, chemical inertness, wear resistance and low density. In addition to automotive applications because of their thermal shock resistance and flame retardancy are used for high-temperature thermal shock zones, such as the fusion energy applications, in gas turbines, aerospace applications, cutting tools, rock drill tips, tools and dies as well as general wear parts, and many others [29]. The interest of science in recent decades toward the magnetic nanocomposites because of their functional properties for which are widely used starting from the field of magnetic fluid catalysis and adsorption, biotechnology, biomedicine, magnetic resonance imaging, data storage, electronics, magneto-optic and photo catalysis to supercapacitors, hyperthermia, drug shipments, remediation of water, collecting energy. When environmental and biomedical and catalytic apply magnetic metal-ceramic nanocomposites because of its porous structure. These composites are composed of a dispersion of nano-particulate $\mathrm{Fe}^{0}, \mathrm{CO}^{0}$, or $\mathrm{Ni}^{0}$ nanoparticles usually in amorphous silica or alumina ceramic matrix [30, 31].

\section{STATUS OF APPLICATION OF NANOCOMPOSITES IN THE WORLD IN THE AUTOMOTIVE INDUSTRIES}

Improving the performance of vehicles in terms of quality elements as well as the reduction of greenhouse gas emissions is the constant tendency of the automotive industry. The main driver of the motor vehicle industry is to increase fuel efficiency and reducing vehicle weight. The application of composites in cars is affected by high production as well as stringent market regulations. According to the International Organization of Motor Vehicle Manufacturers, in 2016, total production of 95 million cars and commercial vehicles. In the following chart according to research [26] provides an overview of the car market in the US with revenues by products in recent years and forecasting to 2025 , Figure 5 . 


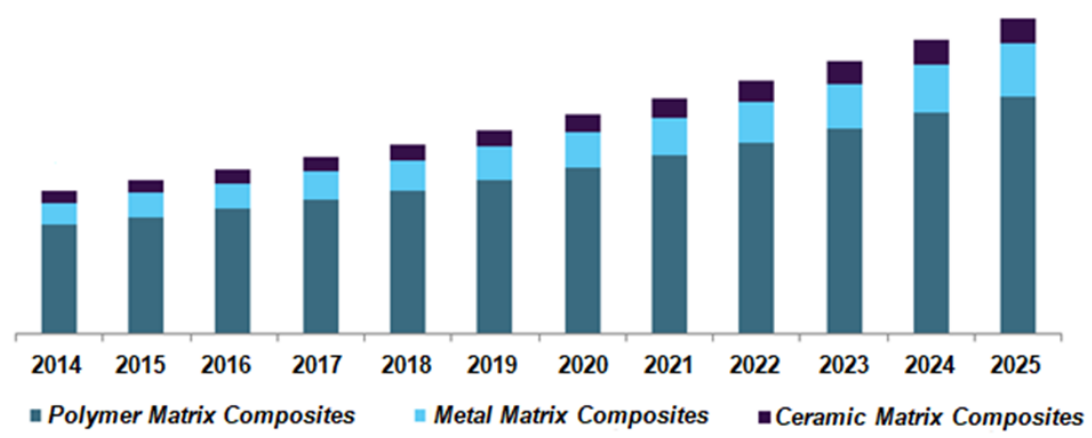

Figure 5. The car market in the US revenue by product, 2014 - 2025 (USD Million) [26]

Growing of carbon emissions due to increased number of vehicles in recent years in the world, launched by governments around the world to react and reconsider the emissions from vehicles. Countries such as China, Japan, Vietnam and Indonesia have implemented various policies in terms of emission standards.

Car manufacturers and composites are well acquainted with the regulations of the countries and producing products that meet specified standards. Automakers believe that reducing vehicle weight is one of the most effective solutions for ensuring compliance and reducing emissions. For every 100 pounds per $45 \mathrm{~kg}$ (from 2 to 3\%), results in low emissions [26].

According to studies [22] of the global vehicle market is projected to grow by $5.3 \%$ in the period from 2018 to 2023 with great possibilities in the areas of passenger cars, commercial vehicles and heavy commercial vehicles segment. The main growth drivers for this market are increasing production of the vehicle, increasing the need to improve the ride quality and the growing need for advanced systems of safety and comfort [22].

According to reports and prognosis [32] of the European market of automotive composites there is a possibility of growth in a variety of applications, exterior, interior, chassis systems, body and others. It is anticipated that the European market of automotive composites by 2021 will reach $\$ 4.1$ billion and is projected to grow by $5.8 \%$ from 2016 to 2021. The main growth drivers for this market are increasing car production and increasing demand for lightweight materials. The European Union has set new standards require that passenger cars must meet $\mathrm{CO}_{2}$ emission target of $95 \mathrm{~g} \cdot \mathrm{km}^{-1}$ (equivalent to $57.9 \mathrm{mpg}$ ) by 2021 , and for the production of light vehicles is $147 \mathrm{~g} \cdot \mathrm{km}^{-1}$ (equivalent to $43.3 \mathrm{mpg}$ ) by 2020 years. The European Commission proposes to improve European standards of fuel economy.

New trends that influence the dynamics of the industry include increasing penetration of thermoplastic and carbon composites. Another emerging trend is in the formation of strategic alliances between the OEMs and the supplier of carbon fiber and the resin in the automotive industry. 


\section{CONCLUSIONS}

The following generalized conclusions can be written from the study performed during presented research:

- The main initiators of growth in demand nanocomposites are increasing car production and increasing demand for lightweight materials. It is expected that the implementation of the structural and operating parts increase the rate because composites act as an excellent substitute for metal parts

- Increasing importance is attached to reducing the weight of vehicles because of improving fuel economy, then to improve vehicle performance and reduce emissions. Based on the review of literature predicts an increase in demand for nanocomposites in the automotive industry in the coming years

- It is expected that the increase in research and development activities nanocomposites lead to an increase in their application in structural and operating parts and thus stimulate the growth of the market. The advantage of using nanocomposites in external components and drive luxury cars have a positive impact on demand in the market. Nanocomposites based on a variety of materials of metal or plastic reinforced with metal or ceramic nanoparticles can significantly improve the strength of parts. Different requirements of the automotive industry, such as improved mechanical, electrical, thermal, corrosion, self-cleaning and antiwear properties, and sensing abilities correspond nanocomposites reinforced with nanoparticles, nanofilms, nanoflakes, nanotubes, nanofibers and

- In the future, attention should be paid, in addition to developing lighter materials, the protection of the environment through increased recycling rates of the vehicle at end of life. Based on the examination papers noted that talking about the difficulties in the recycling of composites and can not give up on their application in the automotive industry, it is necessary to find a proper recycling methods.

\section{ACKNOWLEDGMENTS}

This paper presents the research results obtained within the framework of the projects TR35021, TR35033 and TR35041 financially supported by the Ministry of Education, Science and Technological development of the Republic of Serbia.

\section{REFERENCES}

[1] Sharma, P., Khanduja, D., Sharma, S.: "Dry sliding wear investigation of A16082/Gr metal matrix composites by response surface methodology", Journal of Materials Research and Technology, Vol. 5, No. 1, 2016, pp 29-36.

[2] Suresh, S., Shenbaga Vinayaga Moorthi, N., Vettivel, S.C., Selvakumar, N.: "Mechanical behavior and wear prediction of stir cast $\mathrm{Al}-\mathrm{TiB}_{2}$ composites using response surface methodology", Materials and Design, Vol. 59, 2014, pp 383-396.

[3] Đorđević, Z., Jovanović, S., Veličković, S., Jović, Đ., Milićević, J.: "Influence of application of new material in automotive industry on improving quality of life", $2^{\text {nd }}$ International conference on Quality of Life, Center for Quality, Faculty of Engineering, University of Kragujevac, 2017, Kragujevac, pp 329-332.

[4] Gutowski, V., Yang, W., Li S., Dean, K., Zhang, X.: "Lightweight Nanocomposite Materials, In book: Lightweight and Sustainable Materials for Automotive Applications", 2017, pp 277-302. 
[5] Mavhungte, S.T., Akinlabi, E.T., Onitiri, M.A., Varachia, F.M.: "Aluminum Matrix Composites for Industrial Use: Advances and Trends", Procedia Manufacturing, Vol. 7, 2017, pp 178-182.

[6] Nanowerk; Available from: https://www.nanowerk.com/spotlight/spotid=23934.php, Accessed 20.05.2018.

[7] Mathew, J., Joy, J., George, C.S.: "Potential applications of nanotechnology in transportation: A review", Journal of King Saud University - Science, 2018, open access, In Press, Corrected Proof.

[8] Tiruvenkadam, N., Thyla, P.R., Senthilkumar, M., Bharathiraja, M., Murugesan, A.: "Synthesis of new aluminum nano hybrid composite liner for energy saving in diesel engines", Energy Conversion and Management, Vol. 98, No. 2015, pp 440-448.

[9] Carvalho, O., Buciumeanu, M., Madeira, S., Soares, D., Silva, F.S., Miranda, G.: "Optimization of AlSi-CNTs functionally graded material composites for engine piston rings", Materials and Design, Vol. 80, 2015, pp 163-173.

[10] Ramachandra, M., Abhishekb, A., Siddeshwarc, P., Bharathid, V.: "Hardness and Wear Resistance of $\mathrm{ZrO}_{2}$ Nano Particle Reinforced Al Nanocomposites Produced by Powder Metallurgy", Procedia Materials Science, Vol. 10, 2015, pp 212-219.

[11] Sundaram, M.U., Mahamani, A.: "Development of Carbon Nanotube Reinforced Aluminum Matrix Composite Brake Drum for Automotive Applications", Research and Innovation in Carbon Nanotube-Based Composites, Dr. Brahim Attaf (Ed.), Chapter, 2015.

[12] Ranaa, R. S., Purohit, R., Sonia, V. K., Das, S.: "Development and Wear Analysis of Al- Nano SiC Composite Automotive Cam", Materials Today: Proceedings, Vol. 2, 2015, pp 3586 - 3592.

[13] Asmatulu, R., Nguyen, P., Asmatulu, E.: "Nanotechnology Safety in the Automotive Industry", Elsevier, Amsterdam, 2013, pp 57-72.

[14] Dhanabal, S., Vetrivel, S., Vimal, R.M.: "An overview of hybrid metal matrix composites - characterization, directed applications, and future scope", International Journal of Scientific Engineering and Applied Science, Vol. 1, No. 9, 2015, pp 344350 .

[15] Stojanović, B.: "Tribological behavior of hybrid composites with A356 matrix", Doctoral thesis, Faculty of Engineering University of Kragujevac, 2013.

[16] Džunić, D.: "Friction and wear analisys of Metal Matrix Nanocomposites", Doctoral thesis, Faculty of Engineering University of Kragujevac, 2015.

[17] Gazawi, A.A.: "Microstructure and mechanical properties of aluminium based nanocomposites strengthened with alumina and silicon carbide", Doctoral thesis, University of Waikato, Hamilton, New Zealand, 2014.

[18] Borgonovo, C.: "Aluminum Nano-composites for Elevated Temperature Applications", Thesis, Worcester Polytechnic Institute, 2010.

[19] Saxena, A., Singh, N., Kumar, D., Gupta, P.: "Effect of Ceramic Reinforcement on the Properties of Metal Matrix Nanocomposites", Materials Today: Proceedings, Vol. 4, No. 4, 2017, pp 5561-5570.

[20] Ravi, K. R., Nampoothiri, J., Raj B.: "Nanocomposites: A Gaze through Their Applicationsin Transport Industry", Chapter in book: Nanotechnology for Energy Sustainability, Vol. 2, 2017, pp 831-856. 
[21] Bulei, C., Todor, M.P., Kiss, I.: "Metal matrix composites processing techniques using recycled aluminium alloy”, IOP Conf. Series: Materials Science and Engineering, Vol. 393, No. 012089, 2018, pp 1-7.

[22] Lucintel - Global Management Consulting \& Market Research Firm, Available from: https://www.lucintel.com/, Accessed 10.06.2018.

[23] Dubey, K.A., Hassan, P.A., Bhardwaj, Y.K.: "High Performance Polymer Nanocomposites for Structural Applications", Chapter 5, Materials Under Extreme Conditions, Elsevier, 2017, pp 159-194.

[24] Hassanzadeh-Aghdam, M.K., Ansari, R., Mahmoodi, M.J., Darvizeh, A.: "Effect of nanoparticle aggregation on the creep behavior of polymer nanocomposites", Composites Science and Technology, Vol. 162, 2018, pp 93-100.

[25] Müller, K., Bugnicourt, E., Latorre, M., Jorda, M., Sanz, E. Y., Lagaron, J. M., Miesbauer, O., Bianchin, A., Hankin, S., Bölz, U., Pérez, G., Jesdinszki, M., Lindner, M., Scheuerer, Z., Castelló, S., Schmid, M.: "Review on the Processing and Properties of Polymer Nanocomposites and Nanocoatings and Their Applications in the Packaging”, Automotive and Solar Energy Fields Nanomaterials, Vol. 7, No. 4, 2017, pp 1-47.

[26] Nanocomposite Market Analysis, Market Size, Application Analysis, Regional Outlook, Competitive Strategies And Forecasts, 2015 To 2022”, https://www.grandviewresearch.com/, Accessed 10.06.2018.

[27] Durowaye, S.I., Sekunowo, O.I., Lawal, A. I., Ojo, O.E.: "Development and characterisation of iron millscale particle reinforced ceramic matrix composite", Journal of Taibah University for Science, 2017, Vol. 11, No. 4, pp 634-644.

[28] Đorđević, Z.: “Composite constructions", Faculty of Engineering University of Kragujevac, Kragujevac, 2018.

[29] Bose, N.R.: "Thermal shock resistant and flame retardant ceramic nanocomposites", Woodhead Publishing Series in Composites Science and Engineering, 2013, India, pp 3-50.

[30] Esposito, S., Dell'Agli, G., Marocco, A., Bonelli, B., Allia, P., Tiberto, P., Barrera, G., Manzoli, M., Arletti, R., Pansini, M.: "Magnetic metal-ceramic nanocomposites obtained from cation-exchanged zeolite by heat treatment in reducing atmosphere", Microporous and Mesoporous Materials, Vol. 268, 2018, pp 131-143.

[31] Barrera, G., Tiberto, P., Esposito, S., Marocco, A., Bonelli, B., Pansini, M., Manzoli, M., Allia, P.: „Magnetic clustering of $\mathrm{Ni} 2+$ ions in metal-ceramic nanocomposites obtained from Ni-exchanged zeolite precursors", Ceramics International, Vol. 44, No. 14, 2018, pp 17240-17250.

[32] Growth Opportunities for the European Automotive Composites Markets, Available from: https://www.prnewswire.com/, Accessed 10.06.2018. 